\title{
REGULATION OF STEVIA ORGANOGENESIS UNDER STRESS AND MICRO-CLIMATIC CONDITIONS
}

\author{
Hend K. Ibrahim ${ }^{1 *}$, M.A. Ahmed ${ }^{1}$ and E.I. El-Sarag ${ }^{2}$ \\ 1. Cent. Lab. Agric. Climate, Agric. Res. Cent., Minist. Agric. and Land Reclam., Egypt. \\ 2. Dept. Plant Prod., Fac. Environ. Agric. Sci., Arish Univ., Egypt.
}

\begin{abstract}
This study aimed to evaluate the performance of Stevia (var. Spanti) to in vitro salinity and drought stresses as well as micro climatic conditions. Nodal segments were cultivated on B5 medium under $\left(22 \pm 2^{\circ} \mathrm{C}\right)$ temperature and light intensity (2500 LUX). Different concentrations from $\mathrm{NaCl}(0,1000,2000,3000,4000$ and $5000 \mathrm{ppm})$ and mannitol (0, 2, 4, 6, 8 and 10 bar) were used to study salinity and drought stresses. Moreover, two different temperature degrees (18 and $22^{\circ} \mathrm{C}$ ) with three levels of light intensity (1000, 2000 and $3000 \mathrm{LUX}$ ) were used to study the influence of temperature and light intensity on stevia development. The growth parameters values for both salinity and drought treatments were recorded highest values using $1000 \mathrm{ppm}$ and recorded lowest values using $10 \mathrm{bar}$, respectively. The results showed that stevia plants under $22^{\circ} \mathrm{C}$ and $2000 \mathrm{LUX}$ treatments showed the highest values for each of growth parameters and organic and mineral contents.
\end{abstract}

Key words: In vitro salinity, drought stress, plant growth regulators, microclimate, Stevia rebaudiana Bertoni.

\section{INTRODUCTION}

Stevia rebaudiana Bertoni belonging to Asteraceae family, an important medicinal plant native from Northeastern Paraguay and Southern Brazil. This species is now being cultivated on a large scale in many other countries including Japan, Taiwan, Korea, Thailand and Indonesia for medicinal purposes and for use as a natural sweetener in food products (Sreedhar et al., 2008). Germination and establishment from seeds is often poor and sometimes unsuccessful (Shaffert and Chebotar, 1994). There were two options were studied by Farrar and Davis (2000) for multiplication using tissue culture technique and stem cutting for stevia. They found that tissue culture was the best option for multiplication. Mubarak et al. (2012) evaluated the growth of Stevia rebaudiana under stress

\footnotetext{
* Corresponding author: Tel.: +201016003684

E-mail address: he_kh091@yahoo.com
}

conditions, they illustrated that plantlet growth characters decreased as salinity and drought stress level increased. Drought stress was more sever on plantlet growth than salinity stress. While, Badran et al. (2013) evaluated the differences of plant growth, as well as sweetener material of two types of Stevia rebaudiana under conditions of absence and presence of drought stress. They found that selection based on survival (\%) would be more effective to improve stevioside content of stevia plants in drought stress conditions.

Zeng et al. (2013) indicates that $S$. rebaudiana is mildly tolerant to salt stress. So salt and drought stress may be effective for optimizing the steviol glycoside composition. Also, Pandey and Chikara (2014) reported that increasing $\mathrm{NaCl}$ and mannitol concentration in medium, decreased shoot number, shoot length, root number, 
root length, shoot/root ratio, leaf number, leaf fresh weight, stem dry weight, root dry weight, shoot dry weight and leaf dry weight of stevia. However, rate of proline accumulation increased and protein content was decreased by increasing salt concentration. In this respect, Rathore et al. (2014) investigated the effect of salinity on biochemical parameters in two Stevia genotypes. Chlorophyll amount was observed to be decreased as compared to sugars, proline and phenols with increased salt concentrations. Ghaheri et al. (2017) studied the effect of different concentrations of mannitol on some morphological aspects of stevia under in vitro conditions. They observed that by increasing the concentration of mannitol in medium, shoot length, internode length, fresh weight of plants and growth rate were decreased. Moreover, the results showed that osmotic stress significantly reduces the growth and yield components of $S$. rebaudiana Bertoni.

Concerning micro-climatic conditions, Uddin and Baten (2006) noticed that the temperature of Stevia rebaudiana incubated the culture room was maintained around $25^{\circ} \mathrm{C}$. Hossain et al. (2008) pointed that all cultures of Stevia rebaudiana were grown in an air conditioned culture room illuminated by $40 \mathrm{~W}$ white fluorescent tubes with an intensity varied from 20003000 lux. The photoperiod was maintained as 16 hours light and 8 hours dark. So this study aimed to investigate the effects of plant growth regulators, media composition, in vitro salinity and drought stresses, as well as micro-climatic conditions on growth and development of stevia plants using tissue culture technique.

\section{MATERIALS AND METHODS}

\section{Plant Material and Explants Source}

Stevia (Stevia rebaudiana) explants were obtained from Sugar Crops Research Institute in sterilized jars (4 weeks old).

\section{Explant Sterilization}

Shoot tip and nodal segments (1.5-2.0 $\mathrm{cm})$ were washed under running tap water with mild detergent for 5 minutes, followed by distilled water. Thereafter, in aseptic conditions, the explants were soaked in 5\% $(\mathrm{V} / \mathrm{V})$ Clorox for 10 minutes after has been washed three times with sterile distilled water. Later, it was immersed in $0.15 \%$ mercuric chloride $\left(\mathrm{Hg} \mathrm{Cl} \mathrm{Cl}_{2}\right)$ solution for 1 minute and finally four washes with sterilized distilled water to remove all traces of $\left(\mathrm{Hg} \mathrm{Cl}_{2}\right)$. All steps of the sterilization had been done under (Laminar air flow hood). The explants were cultured on B5 medium including vitamins (Gamborg et al., 1968) in jars containing $50 \mathrm{ml}$ medium, supplemented with 3\% $(W / V)$ sucrose, $0.8 \%(W / V)$ agar and $0.1 \mathrm{~g}$ $\mathrm{L}^{-1}$ myo-inositol. Medium $\mathrm{pH}$ was adjusted to 5.7-5.8, before gelling in all stages and the medium was boiled on the hot plate before autoclaving at $121^{\circ} \mathrm{C}$ for $20 \mathrm{~min}$. The explants (3 explants/ jar) were cultured on medium under complete aseptic conditions and after that the cultures were put in the light and incubated at $22 \pm 2^{\circ} \mathrm{C}$ under a $16 / 8$ $\mathrm{hr}$. day/night photoperiod provided by cool white fluorescent lamps (light intensity $2500 \operatorname{lux})$.

\section{In vitro Stress Tolerance Studies}

Explants were cultivated under six levels of $\mathrm{NaCl}(0,1000,2000,3000,4000$ and $5000 \mathrm{ppm})$ to study the response of stevia to in vitro salinity stress, while, for drought stress, six concentrations of mannitol $(0,15$, $30,45,60$ and 75 grams) were added to B5 basal medium to give $(0,2,4,6,8$ and 10 bar) per liter $(\mathrm{W} / \mathrm{V})$, respectively.

\section{Micro-climatic Conditions}

Explants were cultivated on B5 medium and grown under three levels of light intensity (1000, 2000 and 3000 LUX) in combination with two levels of temperature (18 and $22{ }^{\circ} \mathrm{C}$ ) to study the effect of interaction between light intensity and temperature on stevia development. 


\section{Statistical Analysis}

Experiments were set up in completely randomized design (CRD) with three replicates (three explants per replicate). Data were subjected to analysis of variance (ANOVA) and the statistical difference among the means was least significant difference (LSD) using statistical analysis system (SAS) program (SAS, 1997).

\section{RESULTS AND DISCUSSION}

\section{Effect of Salinity Treatments}

\section{Growth parameters}

The effect of six different $\mathrm{NaCl}$ concentrations $(0,1000,2000,3000,4000$ and $5000 \mathrm{ppm})$ on number of shoots, number of leaves, shoot length $(\mathrm{cm})$, number of roots, root length $(\mathrm{cm})$, plant dry weight, plant fresh weight $(\mathrm{g})$ and leaves fresh weight $(\mathrm{g})$ are presented in Table 1. The growth parameters were significantly affected by different concentrations of $\mathrm{NaCl}$, except plant dry weight. This finding was true in the five $\mathrm{NaCl}$ concentrations, as well as the control (B5 free).

According to measuring the effect of salinity on development parameters of Stevia rebaudiana, the control treatment (B5 free) recorded the highest values of most growth parameters (number of shoots, number of leaves, shoot length and root length), while the concentration of 5000 ppm recorded the lowest values of all growth parameters. The highest values of number of roots was obtained from 1000 ppm of $\mathrm{NaCl}$ treatments. The same results were found by Savithri et al. (2001), Xiong et al. (2002), Abd El-Sadek (2003) and Taleie et al. (2012). They found that plant growth parameters were decreased by increasing the salinity levels.

Results presented in Table 2 indicate that the plant fresh and dry weights, as well as leaves fresh weight were significantly affected by different concentrations of
$\mathrm{NaCl}$. This finding was true in four $\mathrm{NaCl}$ concentrations, as well as the control treatment. Cultivating stevia plants in low concentration of $\mathrm{NaCl}$ leads to increasing fresh weight gain to $(1.38 \mathrm{~g})$. In contrast, increasing $\mathrm{NaCl}$ concentration to $5000 \mathrm{ppm}$ recorded the lowest plant fresh weight $(0.33$ $\mathrm{g})$. The influence of salinity stress furnished favorable conditions for decreasing the plant water content.

Obtained results in Table 2 showed that salinity stress exerted a significant effect on plant dry weight (g). Control traits (B5 free) gave the significantly highest value of dry weight $(0.18 \mathrm{~g})$. Results cleared that dry weight achieved by B5 free outyielded those obtained by both $5000 \mathrm{ppm}$ and 4000 ppm of $\mathrm{NaCl}$ treatments by $66.6 \%$.

Lack of $\mathrm{NaCl}$ gave significantly highest value of leaves fresh weight $(0.49 \mathrm{~g})$. While, $3000 \mathrm{ppm} \mathrm{NaCl}$ gave the lowest value $(0.09 \mathrm{~g})$, these finding agreed with the results reported by Zeng et al. (2013), Rathore et al. (2014), Pandey and Chikara (2015) and Rameeh et al. (2017).

\section{Organic and mineral contents}

Results presented in Table 3 indicate that the percentages of nitrogen, phosphorus, proline and chlorophyll $\mathrm{a}+\mathrm{b}$ were significantly affected by different concentrations of $\mathrm{NaCl}$. This finding was true in the five $\mathrm{NaCl}$ concentrations, as well as the control (B5 free).

Cultivating stevia plants in control $\mathrm{NaCl}$ treatment recorded the highest nitrogen percent $(0.27 \%)$, while, $4000 \mathrm{ppm} \mathrm{NaCl}$ recorded the lowest one $(0.09 \%)$.

Phosphorus percent values of $2000 \mathrm{ppm}$ $\mathrm{NaCl}$ were significantly decreased by about $60 \%$ compared to those of $3000 \mathrm{ppm} \mathrm{NaCl}$. As well as, results cleared that the percentages of proline achieved by B5 free was not fair enough to gave the highest values compared to those obtained by 3000 ppm of $\mathrm{NaCl}$ treatment. Moreover, the 3000 ppm of $\mathrm{NaCl}$ gave the highest values of 
Table 1. Effect of different $\mathrm{NaCl}$ concentrations on number of shoots, number of leaves, shoot length $(\mathrm{cm})$, number of roots and root length $(\mathrm{cm})$ of Stevia rebaudiana

\begin{tabular}{cllclc}
\hline $\begin{array}{c}\text { NaCl concentration } \\
\text { (ppm) }\end{array}$ & No. shoots & No. leaves & $\begin{array}{c}\text { Shoot length } \\
\text { (cm) }\end{array}$ & No. roots & $\begin{array}{c}\text { Root length } \\
\text { (cm) }\end{array}$ \\
\hline Control & $8.00 \pm 1.15^{\mathrm{a}}$ & $28.78 \pm 1.16^{\mathrm{a}}$ & $4.50 \pm 0.35^{\mathrm{a}}$ & $6.33 \pm 1.45^{\mathrm{a}}$ & $3.43 \pm 0.48^{\mathrm{a}}$ \\
1000 & $6.67 \pm 0.88^{\mathrm{a}}$ & $18.22 \pm 1.18^{\mathrm{b}}$ & $3.90 \pm 0.17^{\mathrm{ab}}$ & $6.67 \pm 0.88^{\mathrm{a}}$ & $1.07 \pm 0.19^{\mathrm{b}}$ \\
2000 & $4.00 \pm 0.58^{\mathrm{b}}$ & $16.00 \pm 1.54^{\mathrm{bc}}$ & $3.57 \pm 0.29^{\mathrm{cb}}$ & $6.33 \pm 0.67^{\mathrm{a}}$ & $0.93 \pm 0.29^{\mathrm{b}}$ \\
3000 & $3.67 \pm 0.33^{\mathrm{b}}$ & $16.00 \pm 0.77^{\mathrm{bc}}$ & $3.13 \pm 0.19^{\mathrm{cd}}$ & $4.33 \pm 0.88^{\mathrm{ab}}$ & $0.67 \pm 0.24^{\mathrm{b}}$ \\
4000 & $3.67 \pm 0.67^{\mathrm{b}}$ & $13.78 \pm 0.79^{\mathrm{dc}}$ & $2.87 \pm 0.20^{\mathrm{cd}}$ & $4.33 \pm 0.88^{\mathrm{ab}}$ & $0.63 \pm 0.25^{\mathrm{b}}$ \\
5000 & $3.33 \pm 0.33^{\mathrm{b}}$ & $11.11 \pm 0.97^{\mathrm{d}}$ & $2.70 \pm 0.17^{\mathrm{d}}$ & $1.67 \pm 0.67^{\mathrm{b}}$ & $0.60 \pm 0.27^{\mathrm{b}}$ \\
\hline
\end{tabular}

** Means having the same letter within each column are not significantly differed at 0.05 level, according to LSD test.

Table 2. Effect of different $\mathrm{NaCl}$ concentrations on plantlet fresh and dry weight (g), as well as leaves fresh weight (g) of Stevia rebaudiana

\begin{tabular}{cccc}
\hline $\begin{array}{c}\text { NaCl Concentration } \\
(\mathbf{p p m})\end{array}$ & $\begin{array}{c}\text { Plantlet fresh weight } \\
(\mathbf{g})\end{array}$ & $\begin{array}{c}\text { Plantlet dry weight } \\
(\mathbf{g})\end{array}$ & $\begin{array}{c}\text { fresh weight of } \\
\text { leaves }(\mathbf{g})\end{array}$ \\
\hline Control & $1.38 \pm 1.38^{\mathrm{a}}$ & $0.18 \pm 0.02^{\mathrm{a}}$ & $0.49 \pm 0.15^{\mathrm{a}}$ \\
1000 & $0.70 \pm 0.27^{\mathrm{b}}$ & $0.09 \pm 0.02^{\mathrm{b}}$ & $0.15 \pm 0.06^{\mathrm{b}}$ \\
2000 & $0.55 \pm 0.27^{\mathrm{b}}$ & $0.07 \pm 0.03^{\mathrm{b}}$ & $0.16 \pm 0.07^{\mathrm{b}}$ \\
3000 & $0.51 \pm 0.02^{\mathrm{b}}$ & $0.09 \pm 0.01^{\mathrm{b}}$ & $0.09 \pm 0.02^{\mathrm{b}}$ \\
4000 & $0.34 \pm 0.01^{\mathrm{b}}$ & $0.06 \pm 0.00^{\mathrm{b}}$ & $0.16 \pm 0.02^{\mathrm{b}}$ \\
5000 & $0.33 \pm 0.05^{\mathrm{b}}$ & $0.06 \pm 0.01^{\mathrm{b}}$ & $0.19 \pm 0.03^{\mathrm{b}}$ \\
\hline$* *$
\end{tabular}

** Means having the same letter within each column are not significantly differed at 0.05 level, according to LSD test.
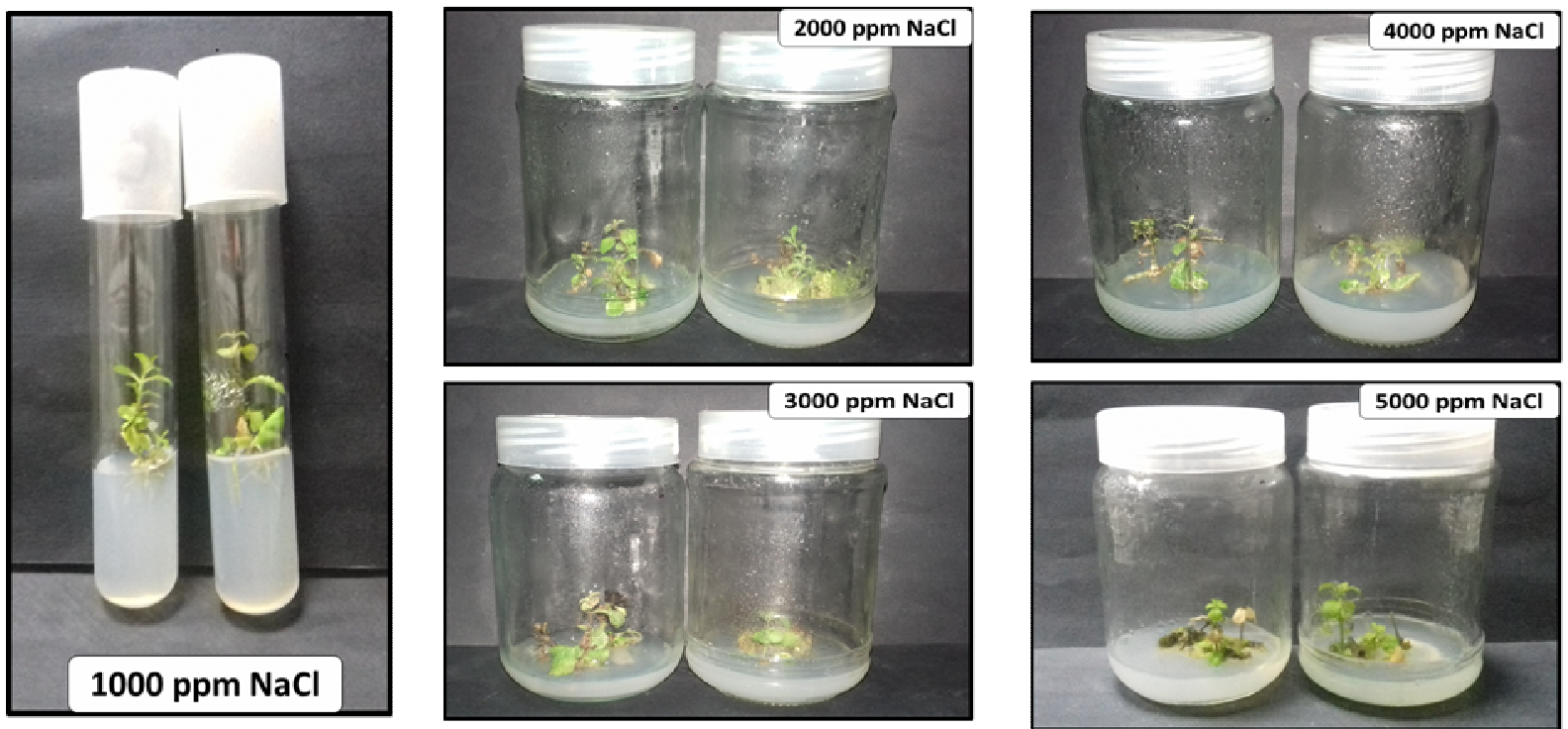

Fig. 1. Effect of $\mathrm{NaCl}$ concentrations on plantlets development parameters of Stevia rebaudiana 
SINAI Journal of Applied Sciences (ISSN: 2314-6079), Vol. (7), Is. (3), Dec. 2018

Table 3. Effect of different $\mathrm{NaCl}$ concentrations on nitrogen, phosphorus, proline percentages as well as chlorophyll a and $b$ contents $\left(\mathrm{mgl}^{-1}\right)$ of Stevia rebaudiana

\begin{tabular}{cccccc}
\hline $\begin{array}{c}\text { NaCl Concentration } \\
\text { (ppm) }\end{array}$ & $\mathbf{N}(\%)$ & $\mathbf{P ~ ( \% )}$ & Proline (\%) & Chl. a & Chl. b \\
\hline Control & $0.27 \pm 0.04^{\mathrm{a}}$ & $0.03 \pm 0.00^{\mathrm{b}}$ & $5.39 \pm 0.09$ & $1.70 \pm 0.18^{\mathrm{a}}$ & $3.26 \pm 0.43^{\mathrm{a}}$ \\
1000 & $0.25 \pm 0.05^{\mathrm{a}}$ & $0.03 \pm 0.00^{\mathrm{ab}}$ & $5.47 \pm 0.02$ & $1.29 \pm 0.12^{\mathrm{ab}}$ & $2.59 \pm 0.17^{\mathrm{ab}}$ \\
2000 & $0.13 \pm 0.00^{\mathrm{cb}}$ & $0.02 \pm 0.00^{\mathrm{b}}$ & $5.50 \pm 0.05$ & $1.37 \pm 0.20^{\mathrm{ab}}$ & $2.49 \pm 0.34^{\mathrm{ab}}$ \\
3000 & $0.22 \pm 0.03^{\mathrm{ab}}$ & $0.05 \pm 0.01^{\mathrm{a}}$ & $6.15 \pm 0.04$ & $1.45 \pm 0.51^{\mathrm{ab}}$ & $2.69 \pm 0.99^{\mathrm{ab}}$ \\
4000 & $0.09 \pm 0.01^{\mathrm{c}}$ & $0.03 \pm 0.00^{\mathrm{b}}$ & $5.96 \pm 0.09$ & $1.28 \pm 0.11^{\mathrm{ab}}$ & $2.34 \pm 0.17^{\mathrm{ab}}$ \\
5000 & $0.12 \pm 0.01^{\mathrm{c}}$ & $0.03 \pm 0.00^{\mathrm{b}}$ & $5.48 \pm 0.03$ & $0.75 \pm 0.18^{\mathrm{b}}$ & $1.36 \pm 0.31^{\mathrm{b}}$ \\
\hline
\end{tabular}

** Means having the same letter within each column are not significantly differed at 0.05 level, according to LSD test.

proline percentage $(6.15 \%)$, while, 0.0 $\mathrm{NaCl}$ (B5 free) gave the lowest one $(5.39 \%)$ in this order.

B5 free $(0.0 \mathrm{NaCl})$ gave the highest values of chlorophyll (a) and chlorophyll (b) $\left(1.70,3.26 \mathrm{mgl}^{-1}\right)$. However, increasing $\mathrm{NaCl}$ concentrations to $5000 \mathrm{ppm}$ gave the lowest values for both chlorophyll $\mathrm{a}$ and $\mathrm{b}$ content $\left(0.75,1.36 \mathrm{mgl}^{-1}\right)$. These results are in agreement with those confirmed by Zeng et al. (2013), Rathore et al. (2014) and Rameeh et al. (2017).

\section{Effect of Drought Treatments}

\section{Growth parameters}

The results of six different mannitol concentrations $(0,2,4,6,8$ and 10 bar) on number of shoots, number of leaves, shoot length $(\mathrm{cm})$, number of roots, root length (cm), plant fresh weight $(\mathrm{g})$, plant dry weight and fresh weight of leaves $(\mathrm{g})$ are presented in Tables 4 and 5 which indicated clearly that the growth parameters were significantly affected by different concentrations of mannitol. This finding was true in four mannitol concentrations, as well as the control.

Increasing mannitol concentration reduced most of growth parameters. The highest number of shoots (8.00) and number of leaves (28.78) were obtained without mannitol, while, the lowest number of shoots (3.67) and number of leaves (16.45) were recorded by the highest concentration of mannitol (10 bar). Correlation between drought and the increase in number of leaves could be attributed to the favorable effect of drought on growth parameters of stevia plants which accounts much for increase in the amount of metabolites synthesized by plant. This increased also the proportion of assimilates migrated to leaves and resulted in a conspicuous increase in number of leaves.

The highest values of shoot length (4.50 $\mathrm{cm})$ and number of roots $(6.33 \mathrm{~cm})$ were recorded for B5 free (control), while, the lowest values of shoot length $(2.73 \mathrm{~cm})$ and number of roots $(0.67)$ were recorded for 8 bar of mannitol. The obtained results showed that root length was effected by increasing mannitol concentrations. Therefore, the highest values of root length was recorded for 2 bar $(3.67 \mathrm{~cm})$, however, the lowest values of root length $(0.27 \mathrm{~cm})$ was obtained from 10 bar of mannitol. These results agreed with the results concluded by: Mubarak et al. (2012), Pandey and Chikara (2014), Pandey and Chikara (2015) and Ghaheri et al. (2017). 
Table 4. Effect of different mannitol concentrations on number of shoots, number of leaves, shoot length $(\mathrm{cm})$, number of roots and root length $(\mathrm{cm})$ of Stevia rebaudiana

\begin{tabular}{cccccc}
\hline $\begin{array}{c}\text { Mannitol } \\
\text { concentration (bar) }\end{array}$ & No. shoots & No. leaves & $\begin{array}{c}\text { Shoot length } \\
(\mathbf{c m})\end{array}$ & $\begin{array}{c}\text { No. } \\
\text { roots }\end{array}$ & $\begin{array}{c}\text { Root length } \\
(\mathbf{c m})\end{array}$ \\
\hline Control & $8.00 \pm 1.15^{\mathrm{a}}$ & $28.78 \pm 1.16^{\mathrm{a}}$ & $4.50 \pm 0.35^{\mathrm{a}}$ & $6.33 \pm 1.45^{\mathrm{a}}$ & $3.43 \pm 0.48^{\mathrm{a}}$ \\
2 & $7.33 \pm 0.88^{\mathrm{a}}$ & $27.33 \pm 1.02^{\mathrm{a}}$ & $3.93 \pm 0.23^{\mathrm{ab}}$ & $3.33 \pm 0.67^{\mathrm{b}}$ & $3.67 \pm 0.29^{\mathrm{a}}$ \\
4 & $6.00 \pm 0.58^{\mathrm{ab}}$ & $19.78 \pm 1.18^{\mathrm{bc}}$ & $3.87 \pm 0.19^{\mathrm{ab}}$ & $3.33 \pm 0.88^{\mathrm{b}}$ & $0.93 \pm 0.18^{\mathrm{b}}$ \\
6 & $5.33 \pm 1.45^{\mathrm{ab}}$ & $21.33 \pm 1.54^{\mathrm{b}}$ & $4.03 \pm 0.18^{\mathrm{a}}$ & $0.33 \pm 0.33^{\mathrm{c}}$ & $0.60 \pm 0.60^{\mathrm{b}}$ \\
8 & $3.67 \pm 0.67^{\mathrm{b}}$ & $17.11 \pm 1.60^{\mathrm{c}}$ & $2.73 \pm 0.38^{\mathrm{c}}$ & $0.67 \pm 0.67^{\mathrm{c}}$ & $0.50 \pm 0.50^{\mathrm{b}}$ \\
10 & $3.67 \pm 0.67^{\mathrm{b}}$ & $16.45 \pm 1.18^{\mathrm{c}}$ & $3.03 \pm 0.43^{\mathrm{cb}}$ & $0.67 \pm 0.67^{\mathrm{c}}$ & $0.27 \pm 0.27^{\mathrm{b}}$ \\
\hline
\end{tabular}

** Means having the same letter within each column are not significantly differed at 0.05 level, according to Least Significant Difference test.

The effect of six different mannitol concentrations $(0,2,4,6,8$ and 10 bar $)$, as well as the control treatment (B5 free) on plantlet dry and fresh weight (g), as well as fresh weight of leaves (g) of Stevia rebaudiana indicated in Table 5. Decreasing mannitol concentrations down to 2 bar led to increase plantlet fresh weight to $(1.45 \mathrm{~g})$ and dry weight to $(0.21 \mathrm{~g})$. In contrast, increasing mannitol concentration up to 10 bar recorded the lowest plantlet fresh weight $(0.43 \mathrm{~g})$ and dry weight to $(0.09 \mathrm{~g})$.

The effect of drought stress on fresh weight of leaves (g) was without a constant trend. More or less, lack of mannitol gave the significantly highest values of leaves fresh weight $(0.49 \mathrm{~g})$. However, increasing mannitol concentration to 4 and 6 bar gave the lowest values $(0.14 \mathrm{~g})$. In this case, Zeng et al. (2013) illustrated that the total dry weight and chlorophyll contents decreased and indicates that $S$. rebaudiana is mildly tolerant to salt stress. So salt and drought stress may be effective for optimizing the steviol glycoside composition. They concluded that mannitol is a six carbon sugar alcohol that often used in laboratories as a medium for inducing osmotic stress in plant and tissue cultures. In addition of mannitol to nutrient solution, over a period of 3-4 weeks that can be effect on gene expression, morphological and physiological characteristics and biochemical content in plants.

\section{Organic and mineral contents}

Results presented in Table 6 indicate that the percentages of nitrogen, phosphorus and proline, as well as chlorophyll $\mathrm{a}$ and $\mathrm{b}$ were significantly affected by different concentrations of mannitol. This finding was true in the five mannitol concentrations as well as the control (B5 free).Cultivating stevia plants in lack of mannitol led to increase the percentages of nitrogen gain to $(0.27 \%)$. In contrast, increasing mannitol concentrations to 6 bar recorded the lowest percentages of nitrogen $(0.06 \%)$.

Obtained results in Table 6 show that drought stress exerted a significant effect on phosphorus percentages. The highest values of phosphorus (0.03) was obtained from B5 free and 8 bar mannitol while, the lowest values (0.02) was obtained from 2 bar mannitol.

The effect of drought stress on chlorophyll $\mathrm{a}$ and $\mathrm{b}$ contents was without a constant trend, increasing mannitol concentrations to 
SINAI Journal of Applied Sciences (ISSN: 2314-6079), Vol. (7), Is. (3), Dec. 2018

Table 5. Effect of different mannitol concentrations on plantlet fresh and dry weight (g) as well as fresh weight of leaves (g) of Stevia rebaudiana.

\begin{tabular}{cccc}
\hline $\begin{array}{c}\text { Mannitol concentration } \\
\text { (bar) }\end{array}$ & $\begin{array}{c}\text { Plantlet fresh } \\
\text { weight }(\mathbf{g})\end{array}$ & $\begin{array}{c}\text { Plantlet dry } \\
\text { weight }(\mathbf{g})\end{array}$ & $\begin{array}{c}\text { Fresh weight of } \\
\text { leaves }(\mathbf{g})\end{array}$ \\
\hline Control & $1.38 \pm 0.17^{\mathrm{a}}$ & $0.18 \pm 0.02$ & $0.49 \pm 0.15^{\mathrm{a}}$ \\
2 & $1.45 \pm 0.36^{\mathrm{a}}$ & $0.21 \pm 0.05$ & $0.36 \pm 0.09^{\mathrm{ab}}$ \\
4 & $0.89 \pm 0.16^{\mathrm{ab}}$ & $0.15 \pm 0.03$ & $0.14 \pm 0.01^{\mathrm{b}}$ \\
6 & $0.61 \pm 0.23^{\mathrm{b}}$ & $0.42 \pm 0.27$ & $0.14 \pm 0.03^{\mathrm{b}}$ \\
8 & $0.53 \pm 0.23^{\mathrm{b}}$ & $0.11 \pm 0.04$ & $0.15 \pm 0.04^{\mathrm{b}}$ \\
10 & $0.43 \pm 0.09^{\mathrm{b}}$ & $0.09 \pm 0.02$ & $0.20 \pm 0.06^{\mathrm{b}}$
\end{tabular}

** Means having the same letter within each column are not significantly differed at 0.05 level, according to LSD test.

Table 6. Effect of different mannitol concentrations on nitrogen, phosphorus, proline percentages as well as chlorophyll a and b contents (mgl) of Stevia rebaudiana

\begin{tabular}{llcccc}
\hline Treatment & $\mathbf{N}(\%)$ & $\mathbf{P}(\%)$ & Proline (\%) & Chl. a & Chl. b \\
\hline Control & $0.27 \pm 0.04^{\mathrm{a}}$ & $0.03 \pm 0.00^{\mathrm{a}}$ & $5.39 \pm 0.86$ & $1.70 \pm 0.18^{\mathrm{a}}$ & $3.26 \pm 0.43^{\mathrm{ab}}$ \\
$\mathbf{2}$ bar & $0.09 \pm 0.01^{\mathrm{bc}}$ & $0.02 \pm 0.00^{\mathrm{d}}$ & $7.00 \pm 0.49$ & $1.48 \pm 0.08^{\mathrm{ab}}$ & $2.68 \pm 0.15^{\mathrm{cb}}$ \\
$\mathbf{4}$ bar & $0.16 \pm 0.03^{\mathrm{b}}$ & $0.02 \pm 0.00^{\mathrm{b}}$ & $5.63 \pm 0.29$ & $1.25 \pm 0.14^{\mathrm{cb}}$ & $2.40 \pm 0.33^{\mathrm{cd}}$ \\
$\mathbf{6}$ bar & $0.06 \pm 0.02^{\mathrm{c}}$ & $0.02 \pm 0.00^{\mathrm{c}}$ & $6.16 \pm 0.28$ & $1.07 \pm 0.02^{\mathrm{c}}$ & $1.79 \pm 0.04^{\mathrm{d}}$ \\
$\mathbf{8}$ bar & $0.10 \pm 0.01^{\mathrm{bc}}$ & $0.03 \pm 0.00^{\mathrm{a}}$ & $5.77 \pm 0.52$ & $1.27 \pm 0.10^{\mathrm{cb}}$ & $2.19 \pm 0.20^{\mathrm{cd}}$ \\
$\mathbf{1 0}$ bar & $0.16 \pm 0.02^{\mathrm{b}}$ & $0.02 \pm 0.00^{\mathrm{c}}$ & $6.06 \pm 1.15$ & $1.77 \pm 0.10^{\mathrm{a}}$ & $3.56 \pm 0.27^{\mathrm{a}}$
\end{tabular}

** Means having the same letter within each column are not significantly differed at 0.05 level, according to LSD test.

10 bar gave the significantly the highest value for each of chlorophyll a content $(1.77 \%)$ and chlorophyll b (3.56\%). However, 6 bar gave the lowest values for both chlorophyll a and $\mathrm{b}(1.07 \%, 1.79 \%)$. These results are in agreement with the findings of Rathore et al. (2014) who investigated the effect of salinity on biochemical characters in two Stevia genotypes. Two node microcuttings were subjected to MS media supplemented with different $\mathrm{NaCl}$ concentrations $(0,25,50$, $75,100,125 \mathrm{mM})$. Chlorophyll amount was observed to be decreased as compared to sugars, proline and phenols with increased salt concentrations.

\section{Effect of Temperature and Light Intensity}

\section{Growth development parameters}

Cultivating stevia plants under $22^{\circ} \mathrm{C}$ and 2000 LUX gave the highest values of all growth development parameters (Table 7) and fig (3). However the lowest values $(2.00,13.11,2.97$, and 2.00) of number of shoots, number of leaves, shoot length and greening rate, respectively, were obtained from interaction between $18^{\circ} \mathrm{C}$ and 1000 LUX.

Necrosis rate results weren't on the constant trend. The interaction between $18^{\circ} \mathrm{C}$ and 1000 LUX produced the highest 
Table 7. Effect of interaction between light intensity and temperature on number of shoots, number of leaves, shoot length $(\mathrm{cm})$, greening and necrosis of Stevia rebaudiana

\begin{tabular}{ccccccc}
\hline $\begin{array}{c}\text { Temp } \\
\left({ }^{\circ} \mathbf{C}\right)\end{array}$ & $\begin{array}{c}\text { Light } \\
(\mathbf{L U X})\end{array}$ & No. shoots & No. leaves & Shoot length & Greening & Necrosis \\
\hline \multirow{2}{*}{18} & 1000 & $2.00 \pm 0.58^{\mathrm{b}}$ & $13.11 \pm 0.80^{\mathrm{d}}$ & $2.97 \pm 0.33^{\mathrm{c}}$ & $2.00 \pm 0.58^{\mathrm{b}}$ & $3.00 \pm 0.58^{\mathrm{a}}$ \\
& 2000 & $3.00 \pm 0.58^{\mathrm{ab}}$ & $15.56 \pm 0.80^{\mathrm{bc}}$ & $4.00 \pm 0.40^{\mathrm{cab}}$ & $4.00 \pm 0.58^{\mathrm{a}}$ & $1.00 \pm 0.58^{\mathrm{b}}$ \\
& 3000 & $2.67 \pm 0.33^{\mathrm{b}}$ & $13.56 \pm 0.59^{\mathrm{dc}}$ & $3.17 \pm 0.27^{\mathrm{cb}}$ & $3.67 \pm 0.33^{\mathrm{a}}$ & $1.33 \pm 0.33^{\mathrm{b}}$ \\
22 & 1000 & $3.00 \pm 0.58^{\mathrm{ab}}$ & $16.00 \pm 0.39^{\mathrm{b}}$ & $3.77 \pm 0.50^{\mathrm{cab}}$ & $3.67 \pm 0.33^{\mathrm{a}}$ & $1.33 \pm 0.33^{\mathrm{b}}$ \\
& 2000 & $5.00 \pm 1.15^{\mathrm{a}}$ & $19.78 \pm 0.79^{\mathrm{a}}$ & $5.03 \pm 0.61^{\mathrm{a}}$ & $4.67 \pm 0.33^{\mathrm{a}}$ & $0.33 \pm 0.33^{\mathrm{b}}$ \\
& 3000 & $3.33 \pm 0.67^{\mathrm{ab}}$ & $16.44 \pm 0.80^{\mathrm{b}}$ & $4.50 \pm 0.40^{\mathrm{ab}}$ & $4.00 \pm 0.58^{\mathrm{a}}$ & $1.00 \pm 0.58^{\mathrm{b}}$ \\
\hline
\end{tabular}

** Means having the same letter within each column are not significantly differed at 0.05 level, according to LSD test.
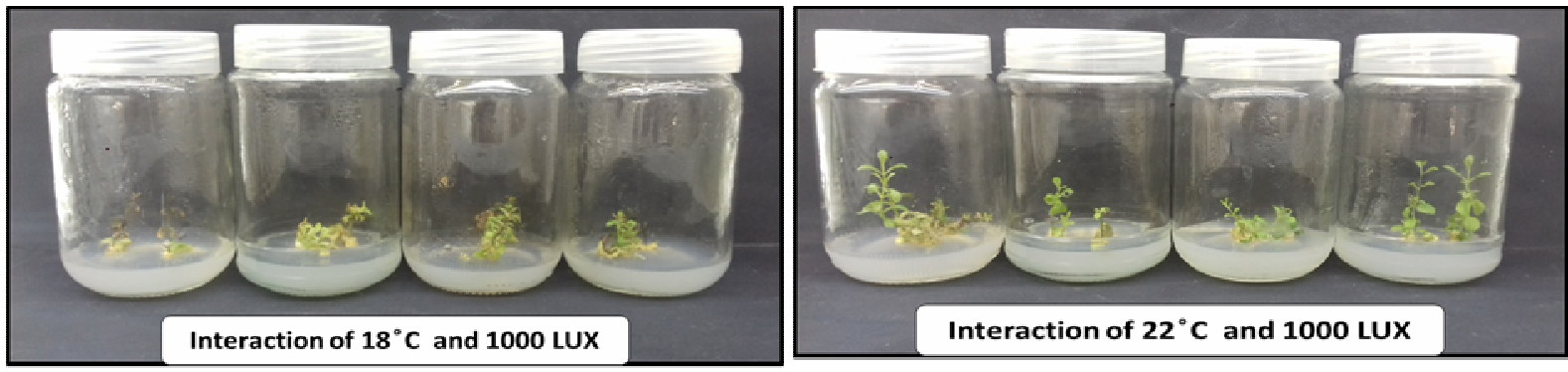

Fig. 2. Effect of interaction between low light intensity (1000 LUX) and temperature on plantlets development parameters of Stevia rebaudiana
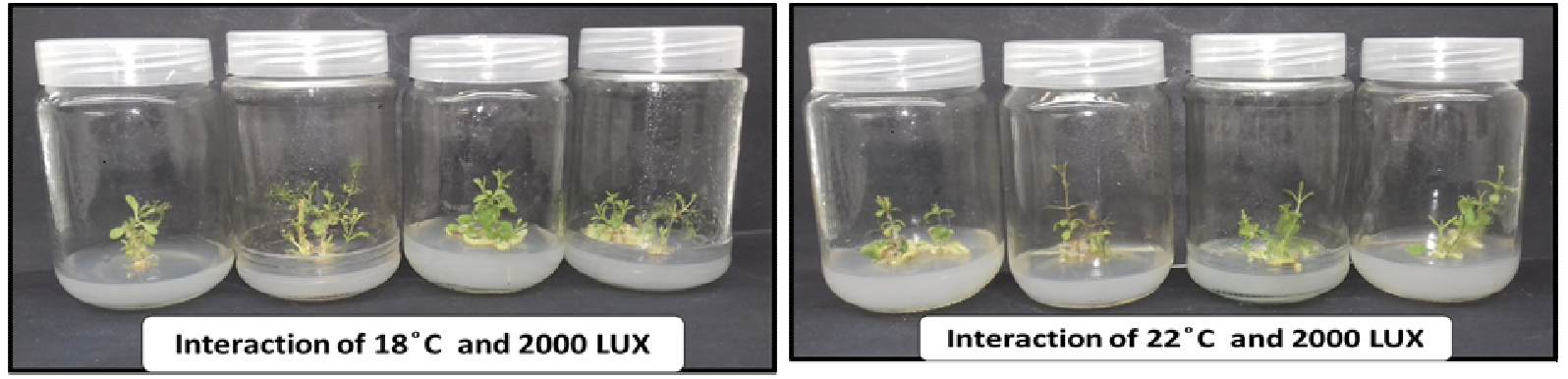

Fig. 3. Effect of interaction between medium light intensity (2000 LUX) and temperature on plantlets development parameters of Stevia rebaudiana
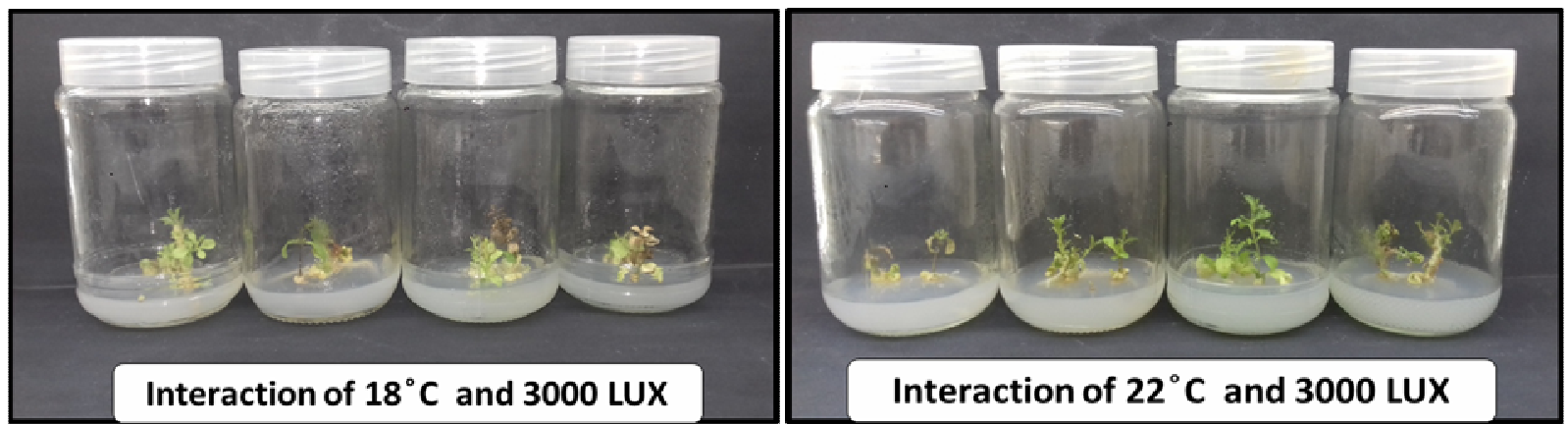

Fig. 4. Effect of interaction between high light intensity (3000 LUX) and temperature on plantlets development parameters of Stevia rebaudiana 
values (3.00) of necrosis rate. Similar results were also reported by Uddin $\boldsymbol{e t} \boldsymbol{a l}$. (2006), Hossain et al. (2008) and Mubarak et al. (2008).

According to the results in Table 8, the highest values of plantlet fresh weight (1.55), dry weight (0.18) and leaves fresh weight $(0.43)$ were obtained from the interaction between $18^{\circ} \mathrm{C}$ and $2000 \mathrm{LUX}$, while, the lowest values of both plantlet fresh and dry weight were obtained from the interaction between $18^{\circ} \mathrm{C}$ and 1000 LUX, but the lowest values of leaves fresh weight were obtained from the interaction between $22^{\circ} \mathrm{C}$ and 1000 LUX. Similar results were also reported by Savithri et al. (2001), Morini et al. (2003), Uddin et al. (2006), Dheeranupattana et al. (2007) and Hossain et al. (2008). In the concern, Mubarak et al. (2008) reported that micropropagation of stevia by shoot tip, gave the highest number of plantlets than nodal segments. The multiplied shoots were cultured on modified MS medium supplemented with different concentrations of BA at $0,0.5,1.0$ and $1.5 \mathrm{mgl}^{-1}$. The best result of shoots number were obtained at $25^{\circ} \mathrm{C}$ under light intensity 3000 lux and BA at $0.5 \mathrm{mgl}^{-1}$.

\section{Organic and mineral contents}

Organic and mineral contents were significantly influenced by the interaction between light intensity and temperature (Table 9).
Results presented in Table 9 indicate that the percentages of nitrogen and phosphorus, as well as the contents of chlorophyll $\mathrm{A}$ and $B$ were significantly affected by the interaction between light intensity and temperature.

Mediate level of light intensity was recorded significantly highest percentage of nitrogen $(0.19 \%)$ under low temperature conditions. Meanwhile, increasing light intensity under conditions of high temperature recorded the lowest value of nitrogen percentage $(0.10 \%)$. The highest value of phosphorus (0.04) was obtained from the interaction between $22^{\circ} \mathrm{C}$ and both 1000 and 3000 LUX, while, the lowest value was obtained from the interaction between $18^{\circ} \mathrm{C}$ and 2000 LUX.

The effect of the interaction of temperature and light intensity on chlorophyll $\mathrm{a}$ and $\mathrm{b}$ contents was without a constant trend; mediate light intensity (2000 LUX) gave significantly the highest value of chlorophyll a (1.76) and chlorophyll b (3.03) under high temperature. Similar results were also reported by Savithri et al. (2001), Morini et al. (2003), Uddin et al. (2006), Dheeranupattana et al. (2007) and Mubarak et al. (2008). In the concern, Hossain et al. (2008) pointed that all cultures of Stevia rebaudiana were grown in an air conditioned culture room illuminated by $40 \mathrm{~W}$ white fluorescent tubes with an intensity varied from 20003000 lux. The photoperiod was maintained as 16 hours light and 8 hours dark.

Table 8. Effect of interaction between light intensity and temperature on plantlet fresh and dry weigh (g) as well as leaves fresh weigh (g) of Stevia rebaudiana

\begin{tabular}{|c|c|c|c|c|}
\hline $\begin{array}{l}\text { Temp. } \\
\left({ }^{\circ} \mathrm{C}\right)\end{array}$ & $\begin{array}{l}\text { Light } \\
\text { (LUX) }\end{array}$ & $\begin{array}{l}\text { Plantlet fresh weight } \\
\text { (g) }\end{array}$ & $\begin{array}{l}\text { Plantlet dry weight } \\
\text { (g) }\end{array}$ & $\begin{array}{l}\text { leaves fresh weight } \\
\text { (g) }\end{array}$ \\
\hline \multirow{3}{*}{18} & 1000 & $0.07 \pm 0.02^{b}$ & $0.09 \pm 0.02^{b}$ & $0.23 \pm 0.05^{\mathrm{ab}}$ \\
\hline & 2000 & $1.55 \pm 0.14^{\mathrm{a}}$ & $0.18 \pm 0.02^{\mathrm{a}}$ & $0.43 \pm 0.12^{\mathrm{a}}$ \\
\hline & 3000 & $1.13 \pm 0.37^{\mathrm{a}}$ & $0.13 \pm 0.04^{\mathrm{ab}}$ & $0.16 \pm 0.07^{b}$ \\
\hline \multirow{3}{*}{22} & 1000 & $1.20 \pm 0.33^{\mathrm{a}}$ & $0.13 \pm 0.03^{\mathrm{ab}}$ & $0.09 \pm 0.03^{b}$ \\
\hline & 2000 & $1.50 \pm 0.23^{\mathrm{a}}$ & $0.18 \pm 0.02^{\mathrm{ab}}$ & $0.29 \pm 0.07^{\mathrm{ab}}$ \\
\hline & 3000 & $0.93 \pm 0.20^{\mathrm{a}}$ & $0.12 \pm 0.02^{\mathrm{ab}}$ & $0.19 \pm 0.06^{\mathrm{b}}$ \\
\hline
\end{tabular}


Table 9. Effect of interaction between light intensity and temperature on nitrogen, phosphorus percentages as well as chlorophyll a and b contents of Stevia rebaudiana

\begin{tabular}{cccccc}
\hline $\begin{array}{c}\text { Temp. } \\
\left({ }^{\circ} \mathbf{C}\right)\end{array}$ & $\begin{array}{c}\text { Light } \\
(\mathbf{L U X})\end{array}$ & $\mathbf{N ~ ( \% )}$ & $\mathbf{P ~ ( \% )}$ & $\mathbf{C h} . \mathbf{a}$ & Ch. b \\
\hline \multirow{2}{*}{18} & 1000 & $0.15 \pm 0.01^{\mathrm{ab}}$ & $0.04 \pm 0.00^{\mathrm{b}}$ & $0.93 \pm 0.19^{\mathrm{c}}$ & $1.61 \pm 0.39^{\mathrm{b}}$ \\
& 2000 & $0.19 \pm 0.03^{\mathrm{a}}$ & $0.03 \pm 0.00^{\mathrm{e}}$ & $1.59 \pm 0.09^{\mathrm{ab}}$ & $3.00 \pm 0.23^{\mathrm{a}}$ \\
& 3000 & $0.18 \pm 0.05^{\mathrm{ab}}$ & $0.03 \pm 0.00^{\mathrm{d}}$ & $1.22 \pm 0.22^{\mathrm{cb}}$ & $2.19 \pm 0.43^{\mathrm{ab}}$ \\
& 1000 & $0.14 \pm 0.00^{\mathrm{ab}}$ & $0.04 \pm 0.00^{\mathrm{a}}$ & $0.79 \pm 0.05^{\mathrm{c}}$ & $1.29 \pm 0.06^{\mathrm{b}}$ \\
22 & 2000 & $0.12 \pm 0.00^{\mathrm{ab}}$ & $0.03 \pm 0.00^{\mathrm{c}}$ & $1.76 \pm 0.17^{\mathrm{a}}$ & $3.03 \pm 0.28^{\mathrm{a}}$ \\
& 3000 & $0.10 \pm 0.01^{\mathrm{b}}$ & $0.04 \pm 0.00^{\mathrm{a}}$ & $1.62 \pm 0.13^{\mathrm{ab}}$ & $2.68 \pm 0.27^{\mathrm{a}}$ \\
\hline
\end{tabular}

** Means having the same letter within each column are not significantly differed at 0.05 level, according to LSD test.

\section{REFERENCES}

Abd El-Sadek, H.B. (2003). Identification of finger prints and marker accessions of Stevia rebaudiana, M. Sc. Thesis, Fac. Agric., Ain-Shams Univ., Egypt.

Badran, A.E.; Mohamed, R.; AbdAlhady, A. and Hassan, W.A. (2013). In vitro evaluation of some traits in Stevia rebaudiana (Bertoni) under drought stress and their relationship on stevioside content. Ame. J. Plant Sci., 6: 746-752.

Dheeranupattana, S.; Wangprapa, M. and Jatisatienr, A. (2007). Effect of sodium acetate on stevioside production of Stevia rebaudiana.ISHS Acta Horticulturae: 786: Int. Workshop on Med. and Aromatic Plants.

Farrar, J.J. and Davis, R.M. (2000). First report of Verticillium dahliae on stevia (Stevia rebaudiana) in North America. Plant Dis, 84:922.

Gamborg, O.L.; Miller, R.; Ojima and K. (1968). Nutrient requirements of suspension cultures of soybean root cells. Experimental Cell Res., 50 (1): 151-158.
Ghaheri, M.; Kahrizi, D. and Bahrami, G. (2017). Effect of mannitol on some morphological characteristics of in vitro Stevia rebaudiana Bertoni. Biharean Biologis, 11 (2): 94-97

Hossain, M.A.; Shamim, A.H.M.; Jahan, T.A. and Hasan, M.N. (2008). Micropropagation of stevia. Int. J. Sustain. Crop Prod, 3 (4): 1-9.

Morini, S.; Fiaschi, G.; Andolfi, L. and Macchia, M. (2003). In vitro propagation of Stevia rebaudiana Bertoni: results with different genotypes. Agricoltura-Mediterranea, 133 (2): 117-123.

Mubarak, M.H.; Belal, A.H; El-Geddawy, I.H.; El-Sarag, E.I. and Nasr, M.I. (2008). Micropropagation of Stevia rebaudiana in vitro. Meeting the challenges of sugar crops and integrated industries in developing countries, Al Arish, Egypt, 293-298.

Mubarak, M.H.; Belal, A.H; El-Dein, T.N. and El-Sarag, E.I. (2012). In vitro response growth Stevia rebaudianato salinity and drought. Minia International Conferencefor 
Agriculture and Irrigation in the Nile Basin Countries, Egypt, 1369 - 1373.

Pandey, M. and Chikara, S.K. (2015). Effect of salinity and drought stress on growth parameters, glycoside content and expression level of vital genes in steviol glycosides biosynthesis pathway of stevia rebaudiana (bertoni). Int. J. Genet., 7 (1): 153-160

Pandey, M. and Chikara, S.K. (2014). In vitro regeneration and effect of abiotic stress on physiology and biochemical content of Stevia rebaudiana 'Bertoni'. J. Plant Sci. and Res., 1(3): 113.

Rameeh, V.; Gerami, M.; Omran, V.G. and Ghavampour, S. (2017). Impact of glycine betaine on salinity tolerance of stevia (stevia rebaudiana bertoni) under in vitro condition. Cercetări Agronomiceîn Moldova, 3 (171): 95105.

Rathore, S.; Singh, N. and Singh, S.K. (2014). Influence of $\mathrm{NaCl}$ on biochemical parameters of two cultivars of Stevia rebaudiana regenerated in vitro. J. Stress Physiol. and Biochem., 10 (2): 287-296

SAS (1997). SAS/STAT user's guide. Statistical Analysis System Institute. Cary, NC, USA.

Savithri, B.; Gupta, S.K.; Tuli, R.; Khanuja S.P.S.; Sharma, S.; Bagchi, G.D.; Anil, K. and Sushil. K. (2001). Photoregulation of adventitious and axillary shoot proliferation in menthol mint, Mentha arvensis. Current Sci., 80 (7): 878-881.

Shaffert, E.E. and Chebotar, A.A. (1994). Development of the female gametophyte in Stevia rebaudiana, after introduction in the south coast of the Crimea. [Russian].
BuletinulAcademiei de Stiinte a Republicii Moldova Stiinte Biologice Si Chimice.2:3-9. In: A new rural industry -stevia - to replace imported chemicals weeteners by David J Midmore and Andrew H Rank, August 2002 .RIRDC Web Publication No W02/022. RIRDC Project No UCQ$16 \mathrm{~A}$.

Sreedhar, R.V.; Venkatachalam, L.; Thimmaraju, R.; Bhagyalakshmi, N.; Narayan, M.S. and Ravishankar, G.A. (2008). Direct organogenesis from leaf explants of Stevia rebaudiana and cultivation in bioreactor. Biologia Plan- Tarum, 52(2): 355-360.

Taleie, N.; Hamidoghli, S. and Hamidoghli, Y. (2012). In vitro plantlet probagation of Stevia rebaudiana Bertoni. South Western J. Horti., Biol. and Environ., 3 (1): 99108.

Uddin, R.A. and Baten, M.A. (2006). In vitro propagation of Stevia rebaudiana Bert in Bangladesh. Afr. J. Biotechnol., 5 (13): 1238-1240.

Xiong, L.Y.; Xu, J.S.; Hong, F.X. and Chen, M.C. (2002). Effects of salinity stress on cytosolic calciuminStevia rebaudiana Bertoni cells. Article in Chinese. School of Life Science/The key Laboratory of Education Ministry for Cell Biology and Tumor Cell Engin., Xiamen Univ.y, Xiamen 361005, China.

Zeng, J.; Chen, A.; Li, D.; Yi, B. and Wu, W. (2013). Effects of salt stress on the growth, physiological responses, and glycoside contents of Stevia rebaudiana Bertoni. J. Agric. and Food Chem., 61 (24): 5720-5726. 


\title{
تنظيم التكثف العضوي للإستيفيا تحت ظروف الإجهاد والمناخ الدقيق
}

\author{
هند خليل إبراهيم'، محمد عبد ربه أحمد'، إيمان إسماعيل السراج'
}

ا ـ المعمل المركزي للمناخ الزر اعي، مركز البحوث الزراعية، وزارة الزر اعة واستصلاح الأراضي، مصر. r- قسم الإنتاج النباتي، كلية العلوم الزر اعية البيئية، جامعة العريش، مصر.

تهدف هذه الدر اسة الي تقييم أداء نبات الاستيفيا (صنف: اسبانتا) بالنسبة لبعض عو امل الإجهاد من ملوحة وجفاف

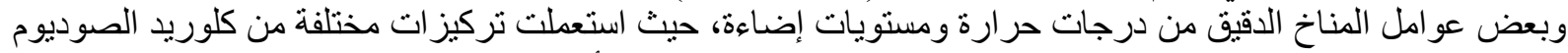

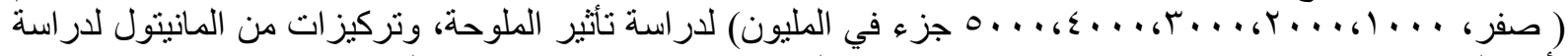

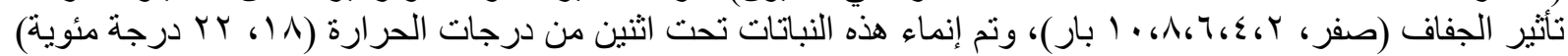

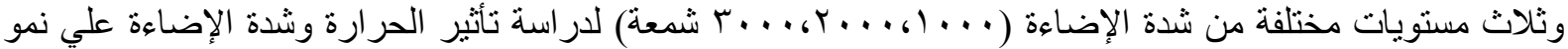

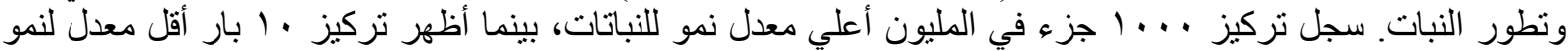

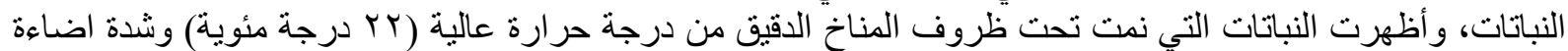

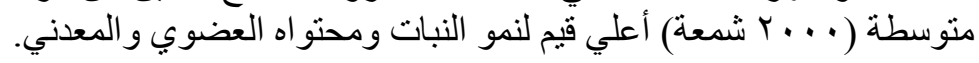
الكلمات الإسترشادية: معاملات الملوحة معملياً، إجهاد الجفاف، منظمات النمو النباتية، المناخ الدقيق، الإستيفيا.

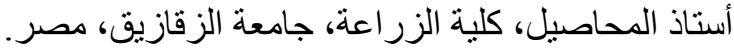

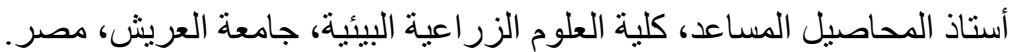

